\title{
Microfungus Flora of Rice (Oryza sativa L.) and Wheat (Triticum durum L.) Grains from Corum Region (Turkey)
}

\author{
Ferudun Kocer (Corresponding author) \\ Research and Development Centre for University-Industry-Public Relations (USKIM), \\ Kahramanmaras Sutcu Imam University, 46050, Kahramanmaras, Turkey \\ E-mail: kocerferudun@gmail.com \\ Adem Imali \\ Yusuf Serefoglu Faculty of Health Sciences, Kilis 7 Aralik University, 79000, Kilis, Turkey \\ E-mail: ademimali@kilis.edu.tr
}

\begin{abstract}
In this study, it was aimed to isolate and define the microfungi flora on rice (Oryza sativa L. var. Osmancik - 97) and wheat (Triticum durum L.) cultivated in Corum province (Turkey). After macroscopic and microscopic criteria, microfungi colonies were defined at the species level. Along with the study, in rice grains, Aspergillus clavatus, Aspergillus niger, Cladosporium orchidis, Penicillium commune, Penicillium crustosum, Penicillium pallidum, and Penicillium brevicompactum were recorded whereas In wheat grains; Alternaria alternata, Curvularia lunata, Curvularia sorghina, Fusarium poae, Microsporon audouinii, Penicillium albicans, Penicillium chrysogenum, Penicillium funiculosum, Penicillium gladioli, and Ulocladium botrytis were defined and reported fot wheat samples.
\end{abstract}

Keywords: Rice, Wheat, Microfungi, Corum, Turkey.

DOI: $10.7176 /$ JSTR/5-9-12

\section{Introduction}

Plant seeds are considered highly effective means of transporting plant pathogens over long distances. There are many studies in the agricultural literature on the international spread of plant diseases as a result of importing seeds contaminated with pathogens. Seed borne diseases have been reported to significantly affect plant growth and productivity (Agarwal and Srivastava, 1981; Dhakar and Jat, 2017). Therefore, agricultural crops and products are of the essential issues for the regions importing the crops and other products.

Cereal products can be contaminated through two different ways, which are sorted as field or plant pathogens contamination (Fusarium spp.) as well as with storage or saporphytic (Aspergillus and Penicillium spp.) (Glenn, 2007; Mohamed et al., 2017).

Based on the previous previous reports, wheat and rice grains can be source of mainly Aspergillus, Fusarium Penicillium which are responsible for common mycotoxin contaminants (Al-Hazmi, 2010; Bensassi et al., 2011; Lutfullah and Hussain, 2012; Mohamed and Shereen, 2017).

Herewith, rice (Oryza sativa L.var. Osmanc1k-97) and wheat (Triticum durum L.) grains collected in Çorum regions were monitored for their microfungi flora.

\section{Materials and Methods}

Preparation of samples

Rice (Oryza sativa L. var. Osmancık-97) and wheat (Triticum durum L.) were collected in Çorum regions. Wheat and rice grains (2008 crops) were subjected to humidification in vitro for one week. One gram of samples were taken from the moistened wheat and rice samples at the end of one week. For homogenized rice and wheat samples, a dilution of $1 / 3$ (for each sample) up to $10^{-3}$ was made (Xie et al., 2007).

\section{Cultivation medium and incubation}

Streptomycine-Rose Bengal Agar (SRBA) (Pitt, 1985), Potato Dextrose Agar (PDA) (Watanabe, 2002), Czapek Agar (CA), (Larone, 1993), Malt Extrakt Agar (MEA) (Samson et al., 2000) media were used. 
The macroscopic and microscopic criteria of the fungi colonies that developed at the end of the incubation period (7-14 days at $25^{\circ} \mathrm{C}$ ) were examined and identified (Harrigan and McCance, 1976; İlhan and Asan, 2001; Karabulut ve Değirmencioğlu, 2002; Mohamed and Shereen, 2017).

\section{Identification of microfungus}

Identification of microfungi for Aspergillus; Samson et al. (2000), Klich (2002) for Penicillium; Pitt (1985), Larone (1993), Samson et al. (2000), and Watanabe (2002) were used whereas other species were defined with Hasenekoglu (1991) and Domsch et al. (1995).

\section{Results and Discussion}

In this study, microfungi flora of rice (Oryza sativa L. var. Osmancık-97) and wheat (Triticum durum L.) grown in Çorum and in the region were investigated in vitro. Alternaria alternata, Curvularia lunata, Curvularia sorghina, Fusarium poae, Microsporon audouinii, Penicillium albicans, Penicillium chrysogenum, Penicillium funiculosum, Penicillium gladioli, Ulocladium botrytis, Aspergillus clavatus, Aspergillus niger, Cladosporium orchidis, Penicillium commune, Penicillium crustosum, Penicillium pallidum, and Penicillium brevicompactum species were identified (Table 1).

Table 1. Species identified in rice (Oryza sativa L.) and Wheat (Triticum durum L.) seeds

\begin{tabular}{|c|c|c|c|}
\hline Species name & $\begin{array}{l}\text { Found } \\
\text { sample }\end{array}$ & $\begin{array}{c}\text { Fungi } \\
(\%)\end{array}$ & Reference \\
\hline Alternaria Nees ex Fr. & & 6 & \\
\hline Alternaria alternata (Fr.) Keissl. & Wheat & & Hasenekoğlu (1991) \\
\hline Aspergillus Mich. Ex Fr. & & 11.75 & \\
\hline Aspergillus clavatus Desm. & Rice & & $\begin{array}{l}\text { Samson et al ( 2000), } \\
\text { Klich (2002) }\end{array}$ \\
\hline Aspergillus niger van Tieghem. & Rice & & $\begin{array}{l}\text { Samson et al ( 2000), } \\
\text { Klich (2002) }\end{array}$ \\
\hline Cladosporium Link: Fries & & 6 & \\
\hline Cladosporium orchidis E.A. \& M.B. Ellis. & Rice & & Hasenekoğlu (1991). \\
\hline Curvularia Boedijn. & & 11.75 & \\
\hline Curvularia lunatus (Wakker) Boedijn & Wheat & & Domsch et al (1980) \\
\hline Curvularia soghina R.G. Shivas \& Sivan. & Wheat & & Hasenekoğlu (1991) \\
\hline Fusarium Link ex Fr. & & 6 & \\
\hline Fusarium poae (Peck) Wollenw. & Wheat & & Hasenekoğlu (1991) \\
\hline Microsporon Gruby. & & 6 & \\
\hline Microsporon audouinii Gruby. & Wheat & & Hasenekoğlu (1991) \\
\hline Penicillium Link ex Gray. & & 47 & \\
\hline Penicillium albicans Bainier. & Wheat & & $\begin{array}{l}\text { Samson et al ( 2000), } \\
\text { Klich (2002) }\end{array}$ \\
\hline Penicillium chrysogenum Thom. & Wheat & & $\begin{array}{l}\text { Samson et al ( 2000), } \\
\text { Klich (2002) }\end{array}$ \\
\hline Penicillium commune Thom. & Rice & & $\begin{array}{l}\text { Samson et al ( 2000), } \\
\text { Klich (2002) }\end{array}$ \\
\hline $\begin{array}{l}\text { Penicillium crustosum Thom (farinosum } \\
\text { Nov.) }\end{array}$ & Rice & & $\begin{array}{l}\text { Samson et al ( 2000), } \\
\text { Klich (2002) }\end{array}$ \\
\hline Penicillium funiculosum Thom. & Wheat & & $\begin{array}{l}\text { Samson et al ( 2000), } \\
\text { Klich (2002) }\end{array}$ \\
\hline $\begin{array}{l}\text { Penicillium gladioli } \text { L. McCulloch \& } \\
\text { Thom. }\end{array}$ & Wheat & & $\begin{array}{l}\text { Samson et al ( 2000), } \\
\text { Klich (2002) }\end{array}$ \\
\hline $\begin{array}{l}\text { Penicillium pallidum } \\
\text { G.Sm(Syn:Geosmithia putterillii Thom) }\end{array}$ & Rice & & $\begin{array}{l}\text { Samson et al ( 2000), } \\
\text { Klich (2002) }\end{array}$ \\
\hline $\begin{array}{l}\text { Penicillium brevicompactum } \\
\text { Dierckx.(stoloniferum Thom.) }\end{array}$ & Rice & & $\begin{array}{l}\text { Samson et al ( 2000), } \\
\text { Klich (2002) }\end{array}$ \\
\hline Ulocladium Preuss & & 6 & \\
\hline Ulocladium botrytis Preuss & Wheat & & Hasenekoğlu (1991) \\
\hline
\end{tabular}


Molds in food can be toxic, especially on wheat and rice, which are commonly consumed cereals. Table 1 shows the $\%$ of fungi defined in the grains of Oryza sativa L. and Triticum durum L. collected in Çorum regions. During the study, Triticum durum L. grains; Penicillium (23.5\%), Curvularia (11.75\%), Fusarium (6\%), Ulocladium (6\%), Alternaria (6\%), Microsporon (6\%) and Oryza sativa L. seeds; Penicillium (23.5\%), Aspergillus (11.75\%), Cladosporium (6\%) genus microfungus species were identified (Table 1). The number of Penicillium species identified from Triticum durum and Oryza sativa seeds is the highest compared to other genus and is found in $23.5 \%$ of each sample. The total number of Penicilium species is higher than the number of other species. The total number of microfungi species of Triticum durum was 10 (62.5\%), whereas it was 7 (37.5\%) in Oryza sativa. In addition, 3 (33.3\%) were identified in Oryza sativa and $6(66.7 \%)$ were identified in Triticum durum. In other words, the Triticum durum situation is also richer in terms of microfungus genus and species diversity than Oryza sativa (Figure 1).

Penicillium species on rice due to the synthesis of secondary metabolite products, consumption of these products have been reported to affect human health in many studies (Ficher et al., 1992; Suttajit, 2000; Signaboubo et al., 2016). Rice (Oryza sativa L.) grown in Çorum and its vicinity with nutritional and economic importance can be expected to produce mycotoxin by identifying $P$. commune, P. crustosum, $P$. pallidum, $P$. brevicompactum species.

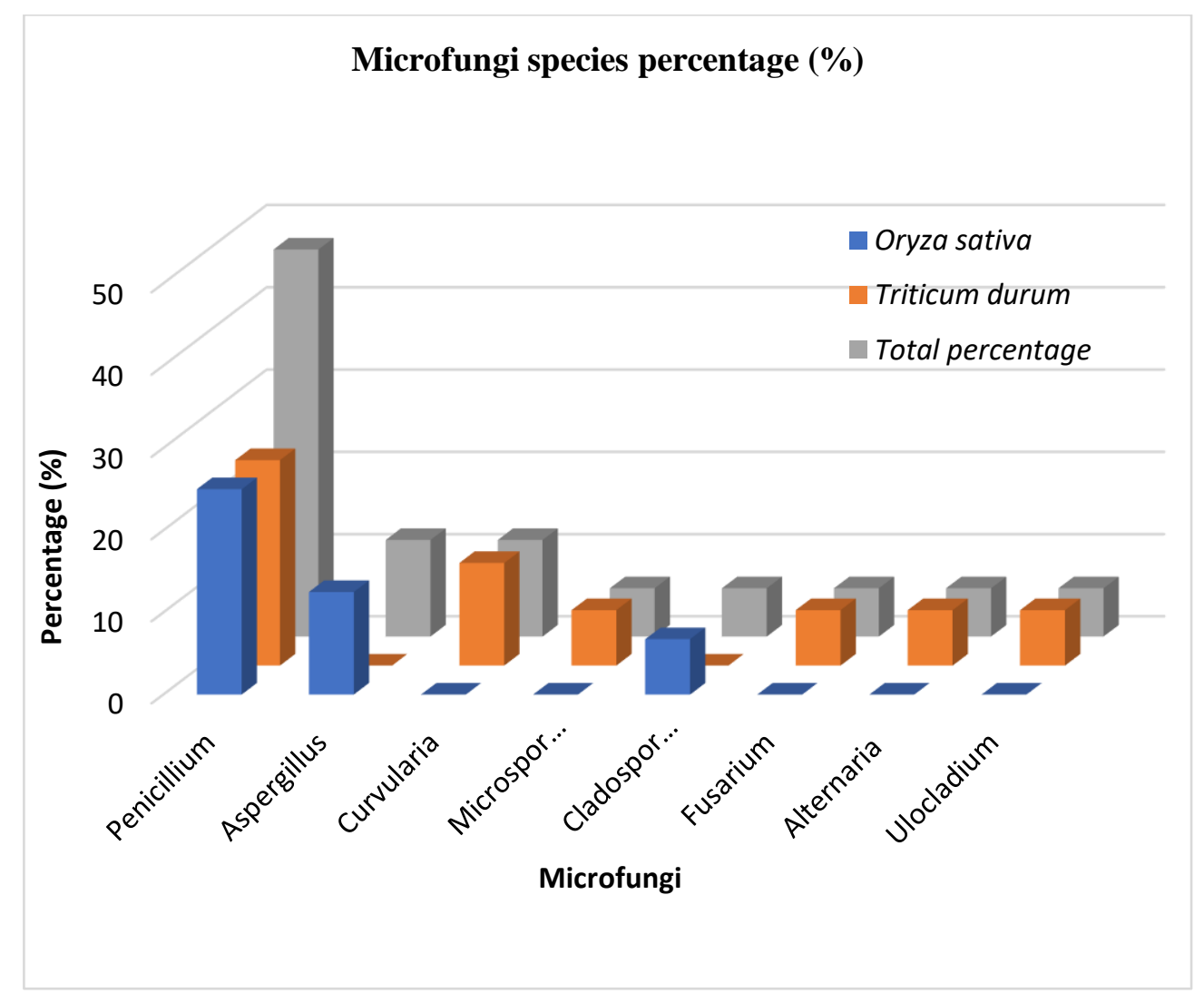

Figure 1. Percentages of fungus species in rice and wheat samples

Colonies of different dilutions $\left(10^{-2}, 10^{-3}\right)$ can be counted on Triticum durum L. in PDA medium; Oryza sativa L. samples showed excessive $(\infty)$ growth at the same dilution rates. Significant decreases were observed in the number of wheat and rice in SRBA cultivated at the same dilutions (Table 2). 
Table 2. Microfungi propagated in the media and the number of species identified

\begin{tabular}{|c|c|c|c|c|c|c|c|c|}
\hline \multirow{2}{*}{$\begin{array}{l}\text { Culture Media } \\
\text { Dilution }\end{array}$} & \multicolumn{6}{|c|}{ PDA } & \multicolumn{2}{|c|}{ SRBA } \\
\hline & $\mathrm{W}^{*}\left(10^{-1}\right)$ & $\mathrm{W}^{*}\left(10^{-2}\right)$ & $\mathrm{W}^{*}\left(10^{-3}\right)$ & $\mathrm{R}^{* *}\left(10-{ }^{1}\right)$ & $\mathrm{R}^{* *}\left(10-^{2}\right)$ & $\mathrm{R}^{* *}\left(10^{-3}\right)$ & $\mathrm{W}^{*}\left(10^{-3}\right)$ & $\mathrm{R}^{* *}\left(10^{-3}\right)$ \\
\hline Number of colonies (cfu/g) & $\infty$ & 278 & 256 & $\infty$ & $\infty$ & $\infty$ & 46 & 184 \\
\hline Number of species identified (pcs) & & 8 & & & 4 & & 2 & 3 \\
\hline
\end{tabular}

* B: Wheat **R: Rice

Likewise, Oryza sativa L. samples were grown 4 times more in Rose bengal medium than Triticum durum L.. Therefore, Oryza sativa L. taxa is weaker than Triticum durum L. and Oryza sativa L. can be recycled faster in nature (Table 2).

In a study conducted in Italy, aflatoxin-producing species of Aspergillus were found to be above the legal levels of mycotoxin in contaminated feed and in milk of animals fed with it (Giorni et al., 2007). For this reason, Aspergillus species should be examined for aflatoxin.

It can be said that microfungi can be formed in almost any environment under suitable humidity and temperature conditions (Adeyeye, 2016; Bradford et al., 2018), and it has suitable climatic conditions for the growth of microfungus and toxin production on cereals especially in rice due to its geographical location.

According to Abbott (2002); It has been reported to cause Alimentary Toxic Aleukia (ATA) by ingestion of Fusarium poae infected grains. The same species found in our study showed parallelism and could be investigated more widely to produce ATA (mycotoxin).

The findings of the study are in parallel with the previous studies because they are in interaction with the air (İmalı et al., 2008). Therefore, Aspergillus spp., Penicillium spp., Cladosporium sp. were isolated from rice (Oryza sativa L. var.) in wheat (Triticum durum L.); Curvularia spp., Fusarium sp., Uloclodium sp., Alternaria sp. genus have been identified, some of which are thought to be allergens.

Frisvad et al., (2007) compared to microfungi Aspergillus niger produced by Fumonosin B2 mycotoxin has a carcinogenic effect and also has similarities with Fusarium species and may be dangerous in terms of food safety due to the presence of many foodstuffs around us. In our study, Aspergillus niger was identified in rice grains and it is hoped to shed light on the following studies in terms of mycotoxic properties of the species.

Over the last 10 years, European wheat products have been increasingly influenced by Fusarium head blight (FHB) infection and high Deoxynivalenol (DON) concentrations in grains. It is argued that this is mainly caused by preventive agricultural practices and cultivation of crops such as wheat and corn simultaneously expanding (Koch, 2006). Turkey's is an important granaries to be due to the cultivation of agricultural land and improvement of the wheat and rice are also taking measures to avoid causing the same of the designated microfungi infection, also it aims to pioneer in the study.

In this study; microfungi have been identified on the level of species, the diagnosis and methods to be used in the prevention of mycotoxins, the procedures to be carried out in the way of protection from these and future studies are expected to constitute a source.

\section{References}

Abbott, S. P. (2002). Mycotoxins and indoor molds, originally published in Indoor Envronment Connections, Vol. 3, Issue 4.

Adeyeye, S. A. (2016). Fungal mycotoxins in foods: A review. Cogent Food \& Agriculture, 2(1), 1213127.

Agarwal, V. K., and Srivastava, A. K. (1981). A simple technique for routine examination of rice seed lots for rice bunt. Seed technology News. 11:1.

Al-Hazmi, N. A. (2010). Determination of Zearalenone (ZEA) in wheat samples collected from Jeddah market, Saudi Arabia. Afr. J. of Microbiol. Res., 4(23): 2513-2519. 
Bensassi, F., Mahdi, C., Bacha, H. and Hajlaoui, M.R. (2011). Survey of the mycobiota of freshly harvested wheat grains in the main production areas of Tunisia. Afr. J. of Food Sci., 5(5): 292298.

Bradford, K. J., Dahal, P., Van Asbrouck, J., Kunusoth, K., Bello, P., Thompson, J., Wu, F. (2018). The dry chain: Reducing postharvest losses and improving food safety in humid climates. Trends in Food Science \& Technology, 71, 84-93.

Dhakar, H., and Jat, R. R. A. (2017). Seed transmission nature of pathogenic seed borne myco flora of wheat (Triticum aestivum L. Em. The Ll.) Seed Samples. Journal of Pharmacognosy and Phytochemistry, 6(6), 590-593.

Domsch, K.H., Gams, W., Anderson, T.H. (1995). Compendium of Soil Fungi, Lubrecht \& Cramer Ltd. Volum II, June.

Ficher, P.J., and Petrini, O. (1992). Fungal saprobes and pathogens as endophytes of rice (Oryza sativa L.) JSTOR: New Phytologis, Vol.120,No.1 pp:137-143.

Frısvad, J. C., Smedsgaard, J., Samson, R. A., Larsen, T.O., Thrane, U. (2007). Fumonisin B2 production by Aspergillus niger, J. Agric. Food Chem., 55, 9727-9732.

Giorni, P., Magan, N., Pietri, A., Bertuzz, T., Pattilani, P. (2007). Studies on Aspergillus section Flavi isolated from maize in Northen Italy. International Journol of Food Microbiology 113:330-338.

Glenn, A. E. (2007). Mycotoxigenic Fusarium species in animal feed. In D. P. Morgavi, \& R. T. Riley (Eds.), Fusarium and their toxins: Mycology, occurrence, toxicity, control and economic impact. Animal Feed Sci. and Technol., 137, 213e240.

Harrigan, W.F., McCance, M.E. (1976). Laboratory methods in food and dairy microbiology. Academic Pres, London, UK.

Hasenekoğlu, İ. (1991). Toprak mikrofungusları. Atatürk Üniversitesi. K.K. Eğt. Fak. Yay., Erzurum.

İlhan, S., and Asan, A. (2001). Soilborne fungi in wheat fields of Kırka Vicinity (Eskişehir-Turkey). Biologia 56 (4): 363-371.

İmalı, A., Yalçınkaya, B., Koçak, M., Koçer, F. (2008). Çorum ili atmosferinde hava ile taşınan allerjen funguslar. Elektronik Mikrobiyoloji Dergisi TR. 06(3):19- 24.

Karabulut, Ö. A., Değirmencioğlu, T. (2002). Hayvan yemi olarak kullanılan buğday danelerinde toksin oluşumuna neden olan fungusların sodyum hidroksit uygulamasıyla engellenmesi, Ulud. Üniv. Zir. Fak. Derg., 16: 129-138.

Klich, M. A. (2002). Identification of common Aspergillus species. united states departman of agriculture agriculturel research service, sourthern regional research center New Orleans, Louisiana USA. ISBN:90-70351-46-3 pp.116.

Koch, H. J., Pringas, C., Maerlaender, B. (2006). Evaluation of environmental and management effects on Fusarium head blight infection and deoxynivalenol concentration in the grain of winter wheat.,Institut fuer Zuckerruebenforschung, Holtenser Landstr.Goettingen, Germany Europ. J. Agronomy 24 357-366.

Larone, D. H. (1993). Media, medically important fungi, a guide to identification, Ame Soc Microbiol, Washington, DC 2 nd ed., p. 204.

Lutfullah, G., Hussain, A. (2012). Studies on contamination level of aflatoxins in some cereals and beans of Pakistan. Food Cont., 23(1): 32-36. 
Mohamed, A. M., Shereen, M. S. (2017). Molecular identification and characterization of Fusarium spp. associated with wheat grains. Int. J. Adv. Res. Biol. Sci. 4(4): 77-87.

Pitt, J. I., and Hocking, A. D. (1985). Fungi and food spoilage. Div. Food Res., CSIRO, Academic Press Sydney, Australia, pp:415.

Samson, R. A., and Pitt J. I. (2000). Integration of modern taxonomic methods for Penicillium and Aspergillus classification. Published by license under the Harwood Academic Publishers imprint, part of The Gordon and breach Publishing Group.

Signaboubo, S., Noumbo, G. T., Roger, K. J. (2016). Seed-borne fungi associated with rice seeds varieties in Bongor, Chad Republic. Int. J. Curr. Microbiol. App. Sci, 5(12), 161-170.

Suttajit, M. (2000). Prevention and control of mycotoxins. FAO Document Catalogue Accession No: 329418. p. 351-362.

Watanabe, T. (2002). Pictorial atlas of soil and seed fungi morphologies of cultured fungi and key to species second edition CRC Press Boca Raton London New York Washington, D.C. ISBN 08493-1118-7.

Xie, G., Li, W., Lu, J., Cao, Y., Fang, H., Zou, H., Hu Z. (2007). Isolation and identification of representative fungi from shaoxing rice wine wheat $Q u$ Using polyphasic approach of culturebased and molecular-based methods J. Inst. Brew. 113(3), 272-279. 